\title{
Komplexní prevence cévních mozkových príhod u pacientů s fibrilací síní
}

Komplexní péče o pacienty s fibrilací síní (FS) vyžaduje mezioborový přístup, který zahrnuje kardiology, arytmology, hematology a neurology. Pražská Nemocnice Na Homolce (NNH) využívá tohoto mezioborového přistupu a zajištuje prevenci cévních mozkových příhod (CMP) u pacientů s FS na špičkové úrovni. Odborníci z tohoto pracoviště prezentovali své zkušenosti v rámci vlastního symposia na XXII. výročním sjezdu České kardiologické společnosti v květnu 2014 v Brně. Souhrn z přednášek prof. MUDr. Petra Neužila, CSc. (primář Kardiologického oddělení NNH), MUDr. Martina Kováře (Neurologické oddělení NNH), MUDr. Lucie Šedivé (Antiarytmická jednotka NNH), MUDr. Jany Matouškové (Kardiologické oddělení NNH) a MUDr. Jozefa Balázse (primář Oddělení klinické biochemie, hematologie a imunologie NNH) zpracovala MUDr. Zuzana Zafarová.

\section{Cílem antikoagulační léčby při FS je snížit riziko ischemických cévních mozkových príhod s minimem krvácivých komplikací}

Cévní mozkové přihody (CMP) invalidizují a někdy i zabíjeji. Zvýšené riziko CMP u pacientů s fibrilací síní (FS) připadá z $92 \%$ na vrub ischemických CMP (iCMP). Smyslem antikoagulačni léčby u pacientů s FS je zabránit iCMP, ale nezvyšovat riziko mozkového krvácení. Dabigatran $150 \mathrm{mg}$ dvakrát denně významně snižil riziko ischemické CMP a intrakraniálního krvácení v porovnání s warfarinem.

Jak připomněl MUDr. Kováŕ ve své prezentaci „Pacient s fibrilací síni - pohled neurologa", FS je často nedostatečně diagnostikována i léčena, přestože jde o zdaleka nejčastější přičinu kardioembolizační CMP. 15-20\% všech CMP dnes souvisí s FS. Pacienti s FS mají CMP pětkrát častěji než běžná populace a tyto př́ihody u nich dvakrát častěji končí fatálně a mají o $50 \%$ vyšší riziko recidivy. iCMP při FS nepřežije $20 \%$ pacientů a $60 \%$ pacientů má trvalé následky. Podle výsledků dvou metaanalýz snižuje podávání warfarinu pravděpodobnost iCMP u pacientů s FS o $64 \%$ v porovnání s placebem a o $38 \%$ v porovnání $s$ kyselinou acetylsalicylovou (ASA). Většina iCMP vzniká u pacientů s nedostatečnou nebo chybějící antikoagulační léčbou. Údaje z prospektivního registru 597 pacientů $s$ FS před zavedením nových perorálních antikoagulancií (NPA) do klinické praxe ukazují, že před první iCMP neužívalo 29 \% žádnou antikoagulační léčbu, 29 \% dostávalo antiagregační léčbu v monoterapii, $29 \%$ subterapeutické dávky warfarinu a pouze $10 \%$ mělo předepsanou účinnou dávku warfarinu (INR $\geq 2$ ). Důvodem může být obávané riziko mozkového krvácení při antikoagulační léčbě. Na misky vah je u pacientů s FS třeba vždy položit riziko iCMP s výskytem 6000 případů v ČR za rok a riziko hemoragické CMP v důsledku podávání antikoagulancií u těchto pacientů. Podle výsledků studie RE-LY by se při léčbě všech pacientů $s$ nevalvulární FS v České republice dabigatranem dvakrát denně $150 \mathrm{mg}$ jednalo odhadem jen o 200 případů za rok! Podstatně vyšší riziko iCMP vyplývá i z dánského národního projektu zahrnujícího 6294 pacientů hospitalizovaných s CMP, u nichž v $92 \%$ šlo o ischemickou príhodu.
Pro klinickou praxi je důležité vědět, jak postupovat, pokud dojde $k$ iCMP při antikoagulační léčbě. MUDr. Kováŕ připomněl, že při terapeutické úrovni antikoagulace je trombolýza kontraindikována. Registr SITS zahrnující 1110 pacientů ovšem ukázal, že při trombolytické léčbě iCMP u pacientů s úrovní antikoagulace INR $\leq 1,7$ nezvyšuje warfarin riziko symptomatického intrakraniálního krvácení, ani nezhoršuje dlouhodobý výsledný funkční stav. Obdobně se nepředpokládá vyšší výskyt této komplikace při trombolýze pacientů léčených NPA s normálními vstupními koagulačními parametry. Tento postup umožňuje i SPC dabigatranu. Znovuzahájení antikoagulace po CMP se doporučuje za jeden den po transitorní ischemické atace (TIA), za tři dny po lehké CMP, za šest dní po středně těžké CMP a za 12 dnů až tři týdny po těžké CMP (obr. 1).

\begin{tabular}{ll}
\hline Závažnost CMP & Znovuzahájení koagulace po \\
\hline TIA & 1 dni \\
$\begin{array}{l}\text { „Lehká" CMP (malý, } \\
\text { neinvaliduzující infarkt) }\end{array}$ & 3 dnech \\
„Středně těžká" CMP & 6 dnech \\
„Těžká" CMP (infarkt postihující & 12 dnech až 3 týdnech \\
velkou část arteriálního povodí) & \\
\hline TIA - transitorní ischemická ataka. \\
H. Heidbuchel, et al., Europace 15 (2013) 625-651.
\end{tabular}

Obr. 1 - Znovuzahájení antikoagulační léčby po CMP

Dabigatran 150 mg dvakrát denně prokázal u pacientů s FS významné snížení rizika ischemických i hemoragických CMP

Nová perorální antikoagulancia nabízejí u pacientů s FS lepši účinnost, bezpečnost a pohodlí ve srovnání s antagonisty vitaminu $K$ (VKA). Snížení rizika ischemické CMP by mělo být primárním cilem antikoagulační léčby u pacientů s FS a tento aspekt by měl být prioritní při výběru antikoagulancia u pacientů s FS. Lékem volby je zde dabigatran v dávkování dvakrát denně 150 mg, který v porovnání s warfarinem významně snižuje riziko iCMP i hemoragických CMP (obr. 2). Rozhodnutí o antikoagu- 


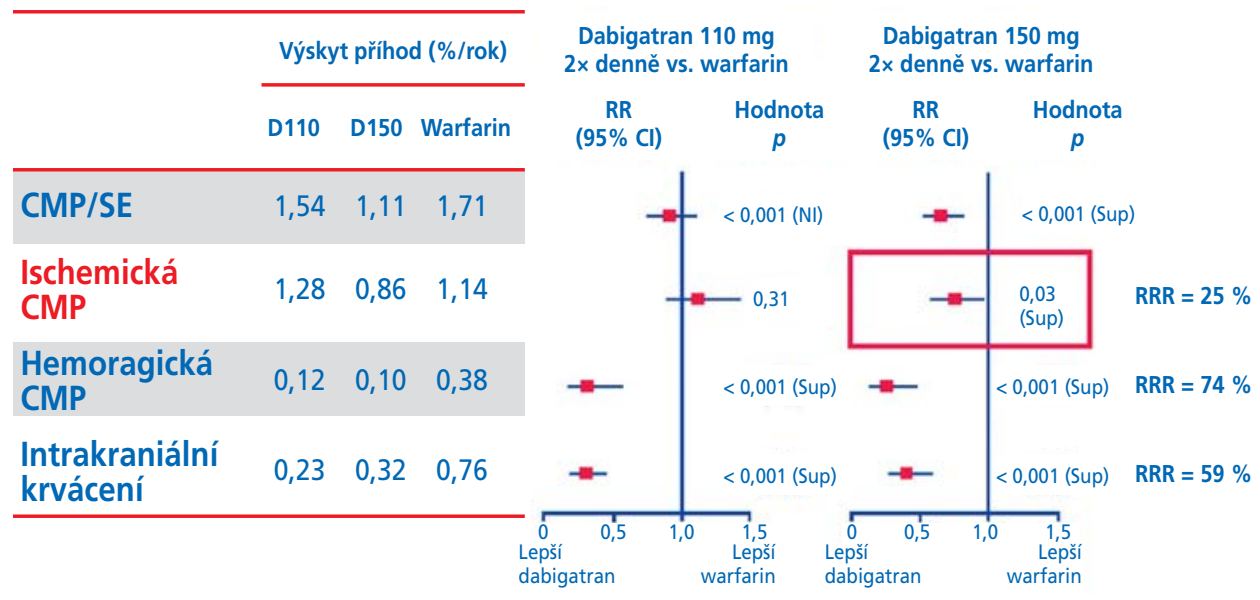

$\mathrm{NI}$ - non-inferiorita; RRR - snížení relativního rizika; SE - systémová embolie; Sup - superiorita.

S.J. Connolly, et al., New England Journal of Medicine 363 (2010) 1875-1876; Pradaxa : SPC, 2013.

Obr. 2 - Dabigatran 150 mg významně snižuje riziko iCMP i mozkového krvácení v porovnání s warfarinem.

\section{lační léčbě musí být vždy individuální a terapie musí re- spektovat SPC a úhradové podmínky}

Na praktická doporučení v prevenci CMP u pacientů s FS a poznatky z klinické praxe se zaměřila MUDr. Šedivá. Připomněla, že pro zhodnocení rizika CMP u nevalvulární FS je doporučeno skóre $\mathrm{CHA}_{2} \mathrm{DS}_{2}-\mathrm{VASc}$. Antikoagulační léčba je doporučena při skóre $\geq 1$. I přes prokázanou účinnost warfarinu v prevenci iCMP u FS ho užívá jen polovina indikovaných nemocných. NPA prokázala podobnou nebo větši účinnost při snížení rizika iCMP a současně nižší riziko hemoragické CMP a intrakraniálního krvácení než wafarin. Proto doporučené postupy ESC pro léčbu FS z roku 2012 upřednostňují NPA před warfarinem. Výsledky studií RE-LY, ARISTOTLE a ROCKET-AF s dabigatranem, apixabanem, respektive rivaroxabanem ve srovnání s warfarinem ukázaly, že dabigatran dvakrát denně 150 mg vedl $k$ významnému snížení jak ischemických, tak hemoragických CMP. To reflektují i výše citovaná doporučení, podle kterých je vhodné při vzniku CMP při léčbě rivaroxabanem nebo apixabanem zvážit převedení na dabigatran dvakrát denně 150 mg, protože rivaroxaban ani apixaban v klinických studiích riziko iCMP ve srovnání s warfarinem významně nesnížily.

V souvislosti se zaváděním NPA do klinické praxe se objevuje řada otázek, jak řešit běžné i specifické situace a stavy. MUDr. Šedivá ukázala nedávno zveřejněné výsledky subanalýzy studie RE-LY týkající se pacientů s chlopenní vadou, kteří tvoří nezanedbatelnou skupinu pacientů s FS. Pacienti s umělou srdeční chlopní nebo hemodynamicky významnou mitrální stenózou byli vyloučeni ze studie RE-LY, ale studie se mohli účastnit pacienti s chlopenní vadou, pokud bylo nepravděpodobné, že $v$ průběhu studie bude nutné intervenční řešení vady. Ve studii RE-LY bylo zařazeno téměř $22 \%$ takových pacientů. Tato subanalýza ukázala, že bez ohledu na antikoagulační léčbu mají pacienti s chlopenní vadou vyšší riziko krvácení. Přínos dabigatranu dvakrát denně 150 mg oproti warfarinu při snížení rizika iCMP i intrakraniálního krvácení byl podobný u všech pacientů nezávisle na přítomnosti chlopenní vady.
Další často se vyskytující klinickou situací u pacientů s FS, kterou řeší arytmolog, je nutnost kardioverze, ablace či implantace kardiostimulátoru nebo kardioverteru. Léčbu dabigatranem není nutno přerušovat $z$ důvodu kardioverze. Rovněž výsledky publikované v roce 2013 neprokázaly vyšší riziko tromboembolických nebo hemoragických komplikací u pacientů podstupujících katetrizační ablaci z důvodu FS při léčbě dabigatranem (léčba krátkodobě přerušena) v porovnání s nepřerušnou léčbou warfarinem. Porovnání dabigatranu s warfarinem u pacientů s FS podstupujících implantaci kardiostimulátoru nebo kardioverteru ukázalo bezpečnost podávání dabigatranu s tendencí ke kratší hospitalizaci a méně závažným krevním ztrátám.

Údaje z dlouhodobého sledování pacientů léčených NPA jak v podmínkách klinických studií, tak v běžné praxi jsou pro lékaře důležité, a proto ve své přednášce představila MUDr. Šedivá také výsledky studie RELY-ABLE, která sledovala dlouhodobou účinnost a bezpečnost pokračující léčby dabigatranem u pacientů, kteří dokončili studii RE-LY. Ve studii RELY-ABLE byl dabigatran za zaslepených podmínek podáván u 2914 pacientů v dávce dvakrát denně 110 mg a u 2937 pacientů v dávce dvakrát denně $150 \mathrm{mg}$ po dobu dalších 2,6 roku. Výsledky prodlouženého sledování odpovídají výsledkưm studie RE-LY. U pacientů, kteří pokračovali v léčbě dabigatranem, zưstal výskyt CMP nízký a během dlouhodobého sledování (až 6,7 roku) se neobjevilo žádné bezpečnostní riziko. Výsledky dlouhodobého sledování antikoagulační léčby v klinické praxi v USA publikované FDA v roce 2013 ukázaly nižší výskyt gastrointestinálního i intrakraniálního krvácení u dabigatranu 150 mg dvakrát denně v porovnání s warfarinem.

\section{Specializovaná ambulance je pro antikoagulační léčbu přínosem}

Na základě zkušeností z klinické praxe potvrdila MUDr. Matoušková účinnost a bezpečnost léčby dabigatranem 
v prevenci CMP a systémové embolie (SE) v reálné klinické praxi. Od zahájení činnosti koagulační ambulance v Nemocnici Na Homolce v roce 2010 nezaznamenali žádnou embolizační přihodu. $Z$ nežádoucích účinků převažovaly zažívací potíže. S krvácivými komplikacemi se setkali ojediněle, významně méně často, než by se dalo očekávat podle výsledků studie RE-LY. Dưvody pro podávání dabigatranu jsou podle MUDr. Matouškové následujíci: dabigatran 150 mg dvakrát denně významně snížil riziko ischemické CMP ve srovnání s warfarinem, při podávání dabigatranu je možná kardioverze/ablace, pouze u dabigatranu jsou $k$ dispozici data o současném podávání duální protidestičkové léčby, je možnost volby ze dvou dávek a zkušenosti z reálné klinické praxe jsou velmi dobré.

MUDr. Matoušková je vedoucí lékařkou koagulační ambulance Nemocnice Na Homolce. Ambulance pracuje od února 2010 a prošlo jí 695 pacientů léčených warfarinem a od srpna 2011 sleduje i 222 pacientů léčených NPA, kteří tvoří asi $46 \%$ všech stávajících pacientů, ale jen 18-20\% kontrolních návštěv. $85 \%$ pacientů užívá NPA z důvodu FS. Standardní dávka dabigatranu je předepsána u 42,8 \% pacientů, snížená dávka (dvakrát 110 mg) u 57,2 \%, ASA je přidána u 7,7 \% pacientů a ASA + clopidogrel u 1,7 \%. 2,6 $\%$ pacientů má implantovanou bioprotézu srdeční chlopně. Bez přerušení podávání dabigatranu podstoupilo 26 pacientů elektrickou kardioverzi a 23 pacientů izolaci plicních žil, přičemž nebyla zaznamenána žádná komplikace tohoto postupu. MUDr. Matoušková společně s MUDr. Balázsem z Oddělení klinické biochemie, hematologie a imunologie Nemocnice $\mathrm{Na}$ Homolce hovořili o monitorování účinku NPA. Pravidelné monitorování není nutné a je doporučeno pouze ve specifických stavech, jako je předávkování, krvá- cení nebo před urgentní operací či trombolýzou, dále z důvodu vyvarování se vysoké expozici dabigatranu v př́padě přítomnosti dalších rizikových faktorů a k ověření compliance s léčbou. Pro dabigatran je $k$ dispozici jednak běžně dostupný aPTT test, jednak specifický test zvaný Hemoclot ke stanovení plazmatické koncentrace dabigatranu. Pro oba testy jsou známé hraniční hodnoty pro zvýšené riziko krvácení (obr. 3).

\section{Okluze ouška levé síně je terapeutickou alternativou u pacientů s FS}

Ouško levé síně je prokazatelně kritickým místem v patogenezi tromboembolie. Okluze ouška je logickou možností léčby s prokázanou non-inferioritou oproti antikoagulační léčbě. Jak řekl prof. Neužil, je vhodným postupem u pacientů s kontraindikací perorální antikoagulace nebo u pacientů, kteři ji nechtěji dlouhodobě užívat, dále u starších nemocných s vysokým rizikem krvácivých komplikací a u nemocných po ablaci s vysokým skóre $\mathrm{CHADS}_{2}$.

Nová perorální antikoagulancia znamenala revoluci v antikoagulační léčbě. Při stejné nebo lepší účinnosti v prevenci iCMP je podávání NPA spojeno s nižším rizikem krvácivých komplikací. Jsou ovšem skupiny pacientů, u nichž je riziko krvácivých komplikací vyšší. Patří mezi ně pacienti s renální insuficiencí a starší pacienti (nad 75 let), pacienti, u nichž je nutné podávat kombinovanou antitrombotickou léčbu. Účinnost antikoagulační léčby je také snížena při nízké adherenci k léčbě. U dabigatranu bylo zjištěno přerušení léčby po jednom roce u $16 \%$ pacientů a po dvou letech u $21 \%$ pacientů. Léčbu rivaroxabanem přeruší $24 \%$ pacientů a apixabanem $25 \%$.

\begin{tabular}{|c|c|c|}
\hline & Dabigatran & Apixaban/rivaroxaban \\
\hline Vrcholová koncentrace & 2 h po podání & 1-4 h po podání/2-4 h po podání \\
\hline Minimální („trough“) koncentrace & 12-24 h po podání & 12-24 h po podání/16-24 h po podání \\
\hline PT & NE & $\begin{array}{l}\text { NE/prodloužen: může indikovat } \\
\text { zvýšené riziko krvácení, nutná } \\
\text { lokální kalibrace. }\end{array}$ \\
\hline INR & NE & NE \\
\hline aPTT & $\begin{array}{c}>2 \times \text { ULN/> } 80 \text { s při min. koncentraci může } \\
\text { ukazovat na vyšší riziko krvácení } \\
\sim 1,5 \times \text { ULN - účinná AK } \\
\text { NORMA - neúčinná AK! }\end{array}$ & NE \\
\hline dTT (Hemoclot) & $\begin{array}{l}\text { Při min. koncentraci: > } 200 \mathrm{ng} / \mathrm{ml} \text { nebo } \\
>65 \text { s zvyšuje riziko krvácení } \\
\text { Známá terapeutická rozmezí }\end{array}$ & NE \\
\hline TT & $\begin{array}{l}\text { NE - extrémně citlivý } \\
\text { NORMA - neúčinná AK! }\end{array}$ & NE \\
\hline ECT & $\begin{array}{c}\geq 3 \times \text { ULN při minimální („trough“) koncentraci } \\
\text { múže ukazovat na vyší riziko krvácení. } \\
\text { NORMA - neúčinná AK! }\end{array}$ & Neovlivněn \\
\hline $\begin{array}{l}\text { Cromogenní metody } \\
\text { stanovení anti-Xa }\end{array}$ & Nevhodné & $\begin{array}{l}\text { Dosud žádná data/Kvantitativní; nejsou } \\
\text { data o prahových hodnotách pro krvácení } \\
\text { nebo trombózu. }\end{array}$ \\
\hline
\end{tabular}

ULN - horní hranice normy.

Upraveno dle R. Čihák, L. Haman, M. Táborský, Cor et Vasa 56 (2014) 52-66; SPC Pradaxa 12/2013.

Obr. 3 - Možnosti monitorování léčby NPA 
Čtyři největší studie věnované tromboembolickým příhodám u FS zahrnující 1181 pacientů ukázaly, že $98 \%$ trombů je lokalizováno v oušku levé síně. Alternativou antikoagulační léčby je tedy endovaskulární okluze ouška levé síně. První okluder PLAATO byl v ČR implantován $v$ roce 2004. Dlouhodobé sledování (58 měsíců) 23 nemocných po implantaci tohoto okluderu v ČR ukázalo výskyt TIA 3,4 \% s průměrnou dobou do vzniku příhody 30 měsíců a $s$ absencí následků. Do studie PROTECT-AF, která hodnotila účinnost a bezpečnost implantace okluderu Watchman, bylo zařazeno 707 pacientů z 59 center v Evropě a USA. Okluze ouška vedla v porovnání s kontrolní skupinou $s$ warfarinem $k$ významnému snížení výskytu primárního sledovaného parametru (CMP, systémová embolie, úmrtí z kardiovaskulárních příčin) o $38 \%$. Ze 463 pacientů, u nichž byla provedena implantace, se objevily komplikace (perikardiální výpotek, krvácení, ischemická CMP, emobolizace okluderu aj.) v 7,7 \% př́padů, přičemž většinou šlo o periprocedurální př́hody. Studie prokázala non-inferioritu okluze ouška v porovnání $s$ léčbou warfarinem a naznačila, že tato léčba může být vhodnou alternativou prevence CMP u pacientů s nevalvulární FS.

Zdá se, že někteří pacienti jsou svoji genetickou výbavou či přidruženými chorobami obecně rizikoví pro antikoagulační léčbu a okluze ouška může být vhodným řešením. Nezodpovězenými otázkami zưstává porovnání relativní efektivity okluze ouška a NPA, porovnání různých prostředků okluze ouška z hlediska rizika vzniku trombu na povrchu okluderu a ekonomická zátěž při pokračování antikoagulační léčby v porovnání s provedením okluze ouška. 